\title{
ANALYSIS OF HEAVY RAIN FROM TYPHOON NUMBER 3 (2017) USING X-BAND MULTIPARAMETER RADAR DATA, KYUSHU, JAPAN
}

\author{
M. Nishio ${ }^{1, *}$, M. Mori $^{2}$ \\ ${ }^{1}$ Information Processing Center, Kurume Institute of Technology, Fukuoka, Japan - nishio@cc.kurume-it.ac.jp \\ ${ }^{2}$ Graduate School of Humanity-Oriented Science and Engineering, Kinki University, Fukuoka, Japan - mori@fuk.kindai.ac.jp
}

Commission IV, WG IV/2

KEY WORDS: X-band MP radar, GIS, Disaster prevention, Rainfall, Sediment disaster

\begin{abstract}
:
The heavy rain on 5-6 July of 2017 was generated by the seasonal rain front that lingered from 30 June until 4 July, and by typhoon No.3 in the Kyushu northern part of Japan (Fukuoka and Oita Prefectures) which occurred at 09:00 on July 2. Such heavy rain caused serious disasters (landslides and flooding). During the large-scale downpour, 2617 damaged dwellings and 39 deaths were recorded in Oita and Fukuoka Prefectures. A new radar system, the X-band MP radar system, provides more detailed rainfall observations than C-band radar, but its special data structure precludes an easy data processing by geographical information systems (GISs) and other software. To overcome this difficulty, we developed an original software that is compatible with GIS. The rainfall amount accumulated by a monitoring system is useful in disaster prevention, as dangerous levels of the accumulated rainfall provide a warning signal.
\end{abstract}

\section{INTRODUCTION}

In 2017, the seasonal rain front stagnated in the Hokuriku and Tohoku region from 30 June through 4 July. Thereafter, it tracked slowly south and stagnated in the vicinity of the Korean peninsula in West Japan. Typhoon No. 3, generated in the south of Okinawa at 09:00 July 2, traveled north over the East China Sea before heading east and landing on Nagasaki City around 08:00 July 4. The typhoon evolved into an extratropical storm in east Japan on 09:00 July 5. The moisture-saturated air flowed largely toward the seasonal rain front, which had stagnated around the Tsushima Island strait under the warm conditions, generating record rainfall in the Kyushu northland of Japan on 5-6 July, 2017. In the heavy-precipitation regions of the Kyushu northland, the rainfall during this period exceeded 500 mm. Moreover, in Asakura City of Fukuoka Prefecture and Hitashi City of Oita Prefecture, the heavy rain within $24 \mathrm{~h}$ surpassed the previous high-rainfall record of the Japan Meteorological Agency (JMA). The small and medium-sized rivers in the mountainous area were inundated and flooded, causing damages and landslide disasters. Traffic was cut off by road collapse, and many villages in Asakura City, the Toho-son, and Hita City were isolated by railway bridge outflows, earthflow insertions, and flooding. The floodwaters carried a large amount of earth, sand, and driftwood. Along with hillside collapse and debris flow, this earth, sand and driftwood buried the river channel, and many households were stranded in the tributaries of the Chikugo, Akatani and Naragaya rivers. The downpour caused landslide disasters (debris flow, landslide, and earthfall) at 275 sites in Fukuoka and Oita Prefectures. Many ground collapses occurred where the rainfall exceeded $200 \mathrm{~m}$ for three hours or less. Most of the collapses occurred in weakened schists and granites. Figure 1 is an aerophotograph of the landslide disaster generated in the Hakimachi vicinity of Asakura City.
The rainfall caused extensive personal suffering, with 37 dead and four missing persons in Fukuoka Prefecture and Liang Province of Oita Prefecture, and many building damages (an estimated 1427 houses were partially destroyed, and approximately 100 houses were damaged by floor-level floods). To prevent rain-related disasters, localized heavy rain (localized torrential rains) in Japan is usually monitored by the Automated Meteorological Data Acquisition System (AMeDAS) operated by the JMA, and by the C-band radar operated by the Ministry of Land, Infrastructure, Transport and Tourism (MLIT) of Japan, with spatial resolutions of $2.5 \mathrm{~km}$ and $1 \mathrm{~km}$, respectively. Rainfall analysis (downpour analysis) based on AMeDAS and the MLIT C-band radar of JMA has been extensively reported (Yamamoto et al., 2017). However, the spatial resolutions of AMeDAS and C-band radar (which recorded the Asakura City and Hita City downpours on July 5-6, 2017) are inadequate for precise rainfall measurements.

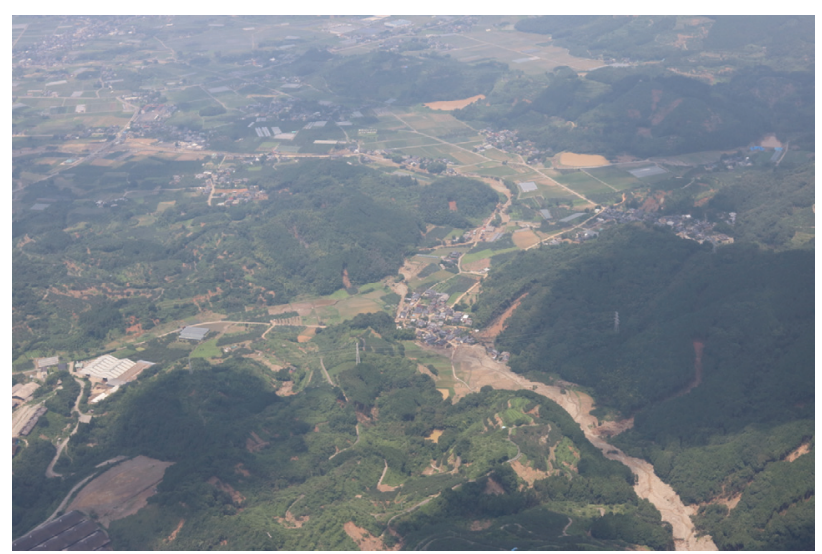

Figure 1. Sediment disasters in Asakura City (Haki-machi).

* Corresponding author 
Therefore, they could not precisely predict the debris flow disasters in Asakura City and Hita City. During the same period, the rainfall data in these two cities were observed by a new radar system, the X-band Multiparameter (MP) radar system, which acquires more detailed rainfall observations than the $\mathrm{C}$ band radar. X-band MP radar observes the local rainfall in nearreal time throughout Japan's territory, supporting appropriate disaster-prevention activity. Its minimum observation area is a 250-m mesh. However, although X-band MP radar accurately measured the rainfall data in Asakura and Hita cities during the disaster, its radar possesses a special data structure that is difficult to process by geographical information systems (GIS) or other software. Moreover, the X-band MP radar data have never been accumulated in a rainfall monitoring system. To resolve these difficulties, we developed a new system using a web-based interface in a GIS framework. An accumulated rainfall monitoring system (Nishio et al., 2015) is crucial for disaster prevention; in particular, the hazard levels of the accumulated rainfall amount are important predictors of disaster occurrences. Using the rainfall data of the MLIT X-band MP radar in Asakura City and Hita City in Hiroshima City, which experienced a large-scale sediment disaster (landslide), this study analyzes the outlines and features of the July 2017 downpour.

\section{METEOROLOGICAL STATE}

The seasonal rain front stagnated in the Hokuriku and Tohoku regions from June 30 to July 4. It then tracked slowly south and stagnated in the vicinity of the Korean peninsula, West Japan, from July 5 to July 10 . Moreover, typhoon No.3 generated in the south of Okinawa at 09:00 July 2 advanced north of the East China Sea before tracking east and landing on Nagasak City around 08:00 July 4. By 09:00 the following day, it had evolved into an extratropical storm east of Japan. Precipitation fell in West Japan, but East Japan was especially hit by the typhoon and seasonal rain front. The moisture-saturated air tended toward the seasonal rain front that had stagnated in the warm conditions around the Tsushima Island strait during 5-6 July. In such situations, the successively generated cumulonimbus rain clouds are maintained in rows, dumping severe and continuous rainfall in one place. Figure 2 shows the surface weather chart of the JMA (15:00 on July 5 of 2017). A weather satellite image of the JMA infrared rays taken at the same time is shown in Figure 3. When expecting a large-scale disaster, the JMA announces an emergency warning. The July 2017 disaster was triggered by abnormally heavy rain in the Kyushu northland (Asakura City and Hita City).

A heavy-rain warning was announced in Fukuoka Prefecture at 17:51 July 5, 2017 and in Oita Prefecture at 19:55 July 5, 2017. Rainfalls of $300 \mathrm{~mm}$ or more at Asakura City (Fukuoka Prefecture) were observed by the AMeDAS station of JMA between 12:00 and 16:00. Moreover, the 24-h accumulated precipitation in Asakura was $500 \mathrm{~mm}$ or more. The precipitation accumulated by the Asakura station of AMeDAS is graphed in Figure 4. In Hitashi City (Oita Prefecture), the station recorded at least $300 \mathrm{~mm}$ of rainfall between 16:00 and 22:00. Moreover, the 24-h accumulated precipitation (1:00-24:00 July 5) in Hita reached at least $330 \mathrm{~m}$, breaking the previous JMA record for this city. Figure 5 graphs the precipitation accumulated by the Hita station of AMeDAS. The 48-h accumulated precipitations in Asakura and Hita, recorded at the observatory of JMA AMeDAS from 5 to 6 July, were $586 \mathrm{~mm}$ and $402.5 \mathrm{~mm}$, respectively. The JMA named the downpour generated in the Kyushu northland between July 5 and July 6 the "Kyushu northern-part downpour in July, 2017."

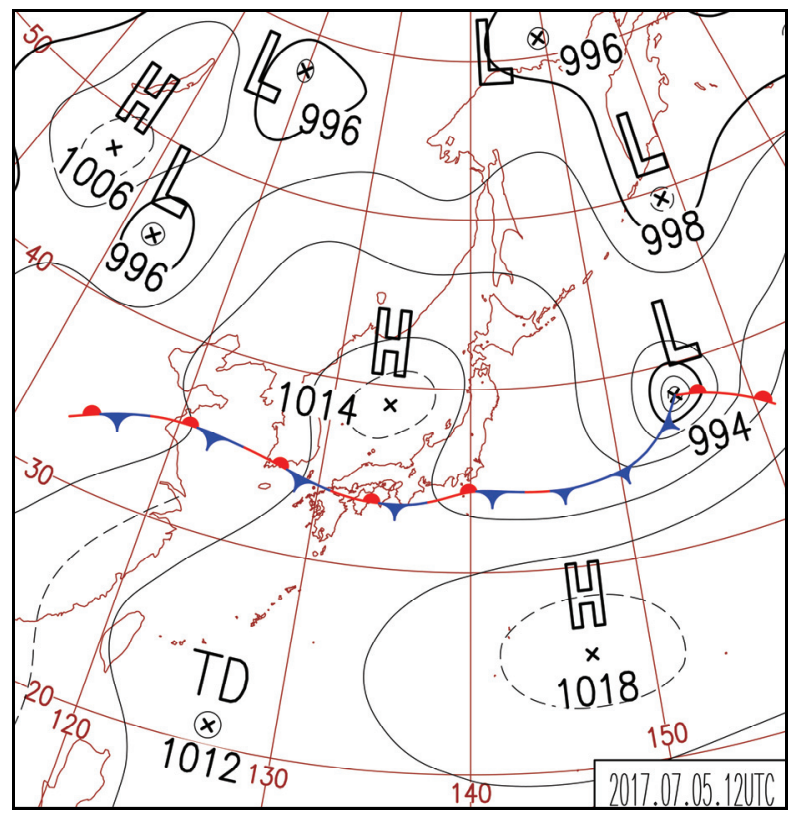

Figure 2. JMA weather chart (12:00 July 5, 2017).

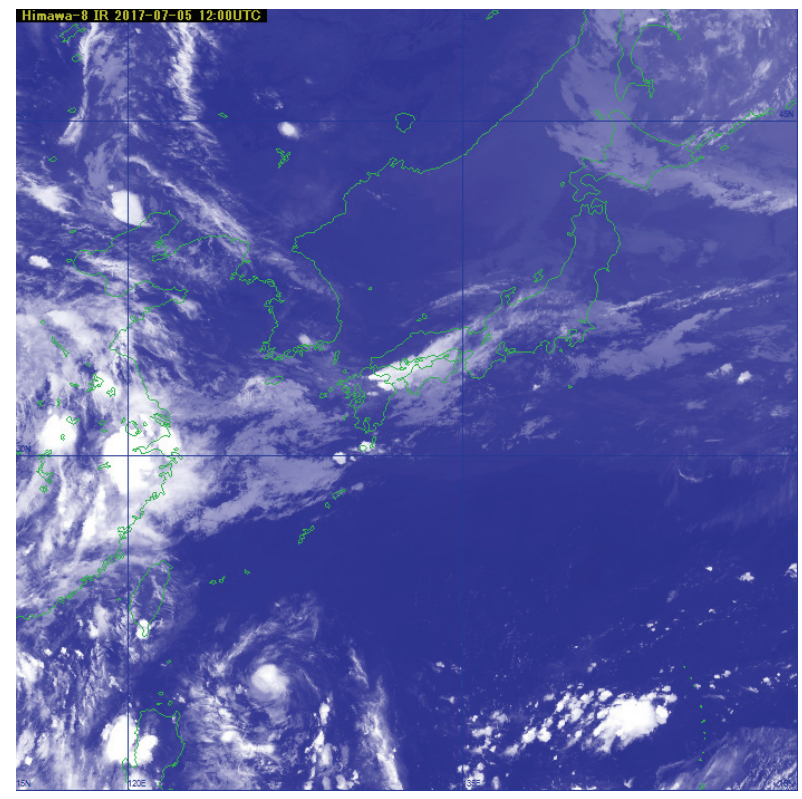

Figure 3. JMA weather satellite image (12:00 July 5, 2017). 
Table 1. Hourly precipitation measured by JMA AMeDAS (2017.7.5 01:00 to 2017.7.6 24:00)

\begin{tabular}{|c|c|c|c|c|c|c|c|c|}
\hline DATE & Maebaru & Asakura & Kuroki & Hita & Inukai & taketa & Kusu & Yabakei \\
\hline 7/5 1:00 & 0 & 0 & 0 & 0 & 0 & 0 & 0 & 0 \\
\hline $7 / 5$ 2:00 & 0 & 0 & 0 & 0 & 0 & 0 & 0 & 0 \\
\hline 7/5 3:00 & 0 & 0 & 0 & 0 & 0 & 0 & 0 & 0 \\
\hline $7 / 54: 00$ & 0 & 0 & 0 & 0 & 0 & 0 & 0 & 0 \\
\hline $7 / 55: 00$ & 0 & 0 & 0 & 0 & 0 & 0 & 0 & 0 \\
\hline $7 / 56: 00$ & 0 & 0 & 0 & 0 & 0 & 0 & 0 & 0 \\
\hline 7/5 7:00 & 3 & 0 & 0 & 0 & 0 & 0 & 0 & 0.5 \\
\hline 7/5 8:00 & 0 & 0 & 0 & 0 & 0 & 0 & 0 & 0 \\
\hline 7/5 9:00 & 0 & 1.5 & 2 & 0 & 0 & 0 & 0 & 1 \\
\hline $7 / 5$ 10:00 & 0 & 0.5 & 2 & 0 & 0.5 & 0 & 1 & 2.5 \\
\hline 7/5 11:00 & 0 & 4 & 23.5 & 0.5 & 0 & 0 & 1 & 0 \\
\hline $7 / 5$ 12:00 & 0 & 17.5 & 21 & 7 & 2.5 & 2.5 & 1.5 & 4.5 \\
\hline $7 / 5$ 13:00 & 0 & 88.5 & 0.5 & 0 & 0.5 & 6 & 0.5 & 3 \\
\hline $7 / 5$ 14:00 & 0 & 46.5 & 0 & 17.5 & 0.5 & 0.5 & 1.5 & 30 \\
\hline $7 / 5$ 15:00 & 0 & 67.5 & 0 & 1 & 20 & 0 & 4 & 13.5 \\
\hline $7 / 5$ 16:00 & 0 & 106 & 0 & 44 & 45 & 0 & 6 & 14 \\
\hline 7/5 17:00 & 0 & 22.5 & 0 & 46.5 & 17.5 & 1 & 15.5 & 15.5 \\
\hline $7 / 5$ 18:00 & 0 & 22 & 0 & 36.5 & 19.5 & 2.5 & 9.5 & 27.5 \\
\hline $7 / 5$ 19:00 & 0 & 44 & 0 & 74.5 & 40.5 & 0.5 & 22.5 & 29 \\
\hline $7 / 520: 00$ & 0 & 59 & 0 & 69.5 & 20.5 & 0.5 & 33.5 & 37.5 \\
\hline $7 / 521: 00$ & 0.5 & 33.5 & 0 & 28 & 28.5 & 0 & 17 & 29 \\
\hline $7 / 5$ 22:00 & 0.5 & 0.5 & 0.5 & 3.5 & 19 & 19.5 & 5 & 31 \\
\hline 7/5 23:00 & 0 & 2 & 0 & 1 & 14 & 21 & 10 & 9.5 \\
\hline $7 / 524: 00$ & 5.5 & 0.5 & 1 & 6.5 & 4.5 & 11 & 2.5 & 7 \\
\hline 7/6 1:00 & 3.5 & 3.5 & 1 & 1 & 3.5 & 10.5 & 0.5 & 4.5 \\
\hline 7/6 2:00 & 47 & 3.5 & 22.5 & 5 & 4 & 26.5 & 2 & 2.5 \\
\hline $7 / 63: 00$ & 33 & 2.5 & 25.5 & 9 & 2.5 & 15 & 4.5 & 6 \\
\hline 7/6 4:00 & 8.5 & 2 & 5 & 0.5 & 3 & 33 & 1 & 3.5 \\
\hline 7/6 5:00 & 5.5 & 3.5 & 3 & 3 & 2.5 & 4 & 2.5 & 4.5 \\
\hline 7/6 6:00 & 14 & 5 & 4.5 & 5 & 3 & 3.5 & 6 & 5.5 \\
\hline 7/6 7:00 & 22 & 5 & 6 & 5.5 & 3.5 & 3.5 & 6.5 & 4.5 \\
\hline 7/6 8:00 & 11 & 1 & 11 & 2.5 & 4.5 & 4 & 3.5 & 6 \\
\hline 7/6 9:00 & 14 & 0 & 1 & 0.5 & 5.5 & 3 & 2.5 & 1 \\
\hline $7 / 6$ 10:00 & 20 & 3.5 & 0 & 0.5 & 3 & 1.5 & 0 & 0.5 \\
\hline 7/6 11:00 & 15.5 & 1.5 & 0 & 1.5 & 0.5 & 0 & 0.5 & 1 \\
\hline $7 / 6$ 12:00 & 0.5 & 6 & 0 & 0.5 & 0 & 0.5 & 0 & 0 \\
\hline $7 / 6$ 13:00 & 0.5 & 0.5 & 0 & 2 & 0 & 0 & 0.5 & 0.5 \\
\hline $7 / 614: 00$ & 0.5 & 1.5 & 0 & 2.5 & 0 & 0 & 0 & 1 \\
\hline $7 / 6$ 15:00 & 0 & 0.5 & 1 & 0 & 0 & 0 & 0.5 & 0 \\
\hline 7/6 16:00 & 0 & 0 & 0 & 0 & 0.5 & 0.5 & 0 & 0 \\
\hline 7/6 17:00 & 0.5 & 0 & 0.5 & 0 & 0 & 0 & 0 & 0 \\
\hline 7/6 18:00 & 1.5 & 0.5 & 2 & 0 & 0 & 0 & 0 & 0 \\
\hline 7/6 19:00 & 2.5 & 0.5 & 1.5 & 1 & 0 & 0.5 & 1 & 0.5 \\
\hline $7 / 620: 00$ & 16 & 0.5 & 0 & 0.5 & 0.5 & 0.5 & 0 & 0.5 \\
\hline $7 / 621: 00$ & 6.5 & 4 & 6 & 1 & 0 & 0.5 & 0.5 & 0 \\
\hline 7/6 22:00 & 7.5 & 3.5 & 11.5 & 5.5 & 0 & 3 & 2 & 1 \\
\hline 7/6 23:00 & 9 & 6.5 & 12.5 & 5 & 3 & 2 & 4 & 1.5 \\
\hline 7/6 24:00 & 5 & 15 & 4.5 & 14.5 & 0.5 & 1.5 & 13 & 6 \\
\hline $\begin{array}{l}\text { Rainfall } \\
\text { total }\end{array}$ & 253.5 & 586 & 169.5 & 402.5 & 273 & 178.5 & 182 & 305.5 \\
\hline
\end{tabular}

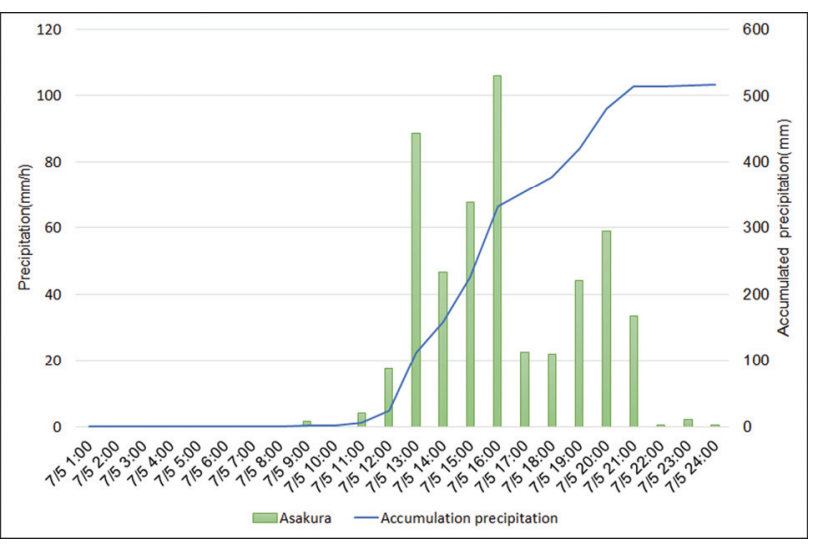

Figure 4. Accumulated precipitation at the JMA AMeDAS Asakura station.

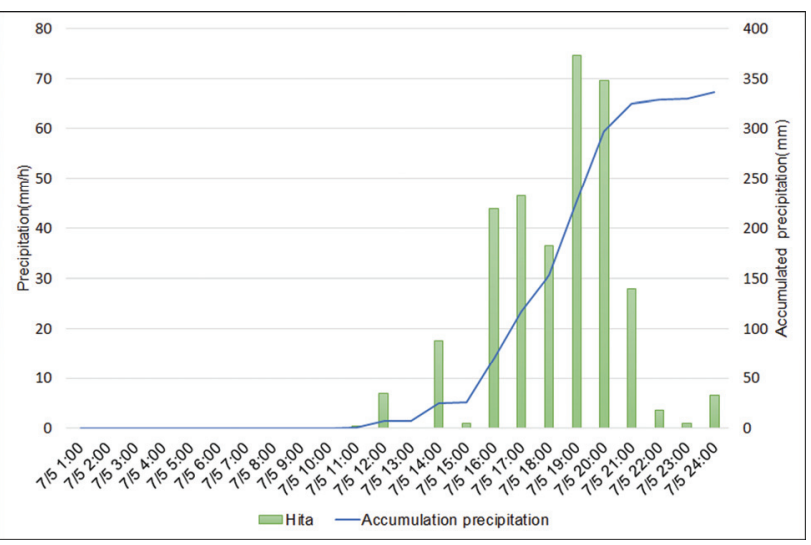

Figure 5. Accumulated precipitation at the JMA AMeDAS Hita station.

\section{ANALYSIS OF PRECIITATION}

The X-band MP radar observes the local rainfall in near-real time. Therefore, the data of flood damage and landslide disaster caused by localized torrential and heavy rains (downpours) can be analyzed for appropriate river management and disaster prevention activity. The observation radius of X-band MP radar is $60 \mathrm{~km}$ (versus $120 \mathrm{~km}$ for the C-band radar), enabling detailed observations of regional heavy rain and the gauging of large-area rainfall. The high resolution of the X-band MP radar is enabled by its shorter wavelength $(8-12 \mathrm{GHz})$ than the $\mathrm{C}$ band radar (4-8 GHz). Raindrop shapes are discerned by the transmission of vertically and horizontally polarized light. The rainfall can be deduced from the flatness and other shape properties of the raindrops. Such highly accurate, real-time rainfall data require no correction by the ground rain gauge.

The movement direction and transfer rate of the raindrops, which are useful for rainfall prediction, can be deduced from the Doppler function. The frequency and resolution of X-band MP radar observations exceed those of $\mathrm{C}$-band radar by 4 and 16 times, respectively. X-band MP radar has a 250-m mesh minimum observation area, and a delivery period of $1 \mathrm{~min}$.

However, as mentioned above, the special data structure of $\mathrm{X}$-band MP radar is difficult to process by GIS and other software. Therefore, we developed an original GIS-compatible 
software for X-band MP radar. The conversion of X-band MP radar rainfall data into GIS data is shown in Figure 6. Using the rainfall data collected by the X-band MP radar during July 5-6 of 2017 and the GIS results, we analyzed the expansion range of the forecasted disaster generation point. The JMA weather information (AMeDAS) constitutes the basic climate observations over the whole Japanese territory. Figure 7 shows the information at the observation points in Asakura and Hita. The precipitation information during the disaster (5-6 July, 2017) was captured by the regional observing system (AMeDAS) of JMA, which is commonly used by local governments. Prior to data analysis at disaster sites, the GIS is inputted with the JMA AMeDAS precipitation information, and with the rainfall information of the X-band MP radar for rainfall analysis. The Fukuoka District Meteorological Observatories reported the amount of rainfall in the Fukuoka and Oita Prefectures during the heavy-rain period.

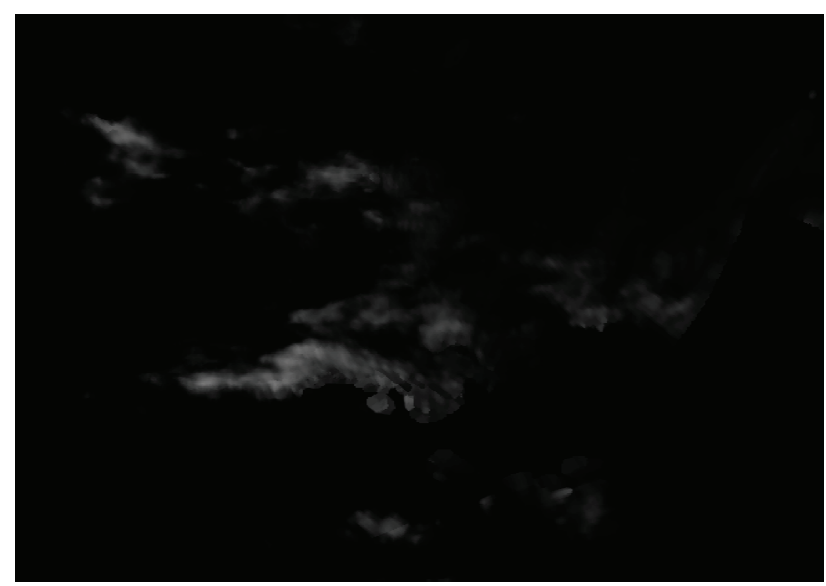

Figure 6. Conversion result of the rainfall data measured by the X-band MP radar (2017.7.5 13:00).

According to their rain gauges, heavy rain began at 13:00 July 5 and continued until 24:00 July 5. Severe rain $(>300 \mathrm{~mm}$ ) between 13:00 and 16:00 at the Asakura station was reported by the JMA AMeDAS rain gauge of Fukuoka Prefecture. The adjacent Hita station (JMA AMeDAS) recorded $300 \mathrm{~mm}$ or more rainfall between 12:00 and 24:00. The JMA AMeDAS Asakura station had accumulated $500 \mathrm{~mm}$ or more precipitation by 24:00 July 5 .

In the precipitation analysis, we applied the rainfall information of the X-band MP radar in the vicinity of the Asakura and Hita stations (AMeDAS), where the disaster occurred, and which was close to the center of the localized torrential rain region. Specifically, we analyzed the rainfall information acquired by the X-band MP radar in the vicinity of the Miri observation point (AMeDAS) in Asakura and Hita, the site of a disaster event. The site was almost centralized in a region of localized torrential rain. Figures 7-13 present the precipitation information captured by the X-band MP radar during 13:00-17:00, which was input to the GIS. The images confirm that the X-band MP radar correctly captured the localized torrential rain. To thoroughly analyze the rainfall amount in the disaster region, we also prepared a GIS visualization (an isohyetal map). Figure 14 shows the result of the rainfall analysis based on the X-band MP radar. Our system correctly determined the regional rainfall amount from the $\mathrm{X}$ band MP radar data.

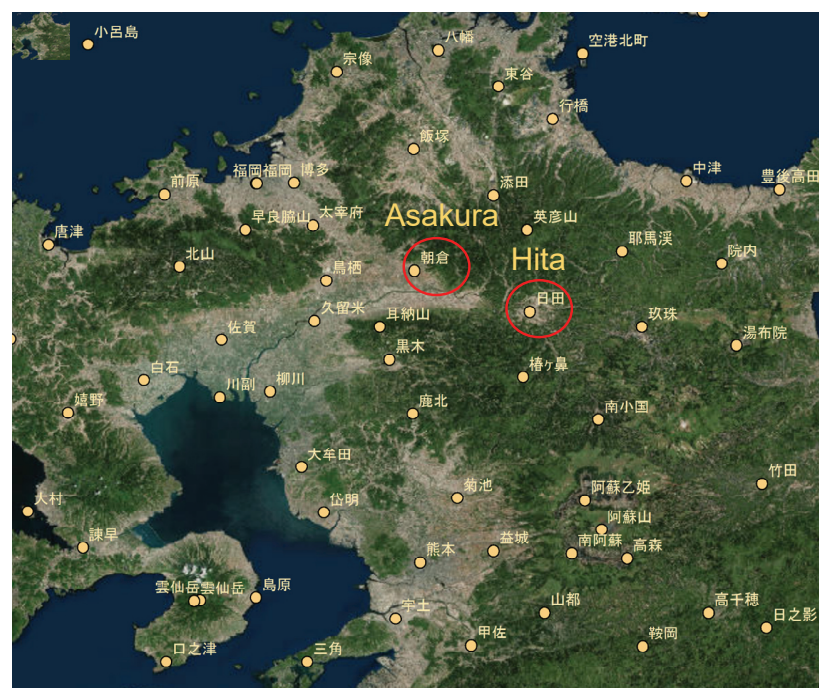

Figure 7. Information on observation point in the vicinity of the JMA AMeDAS stations at Asakura and Hita.

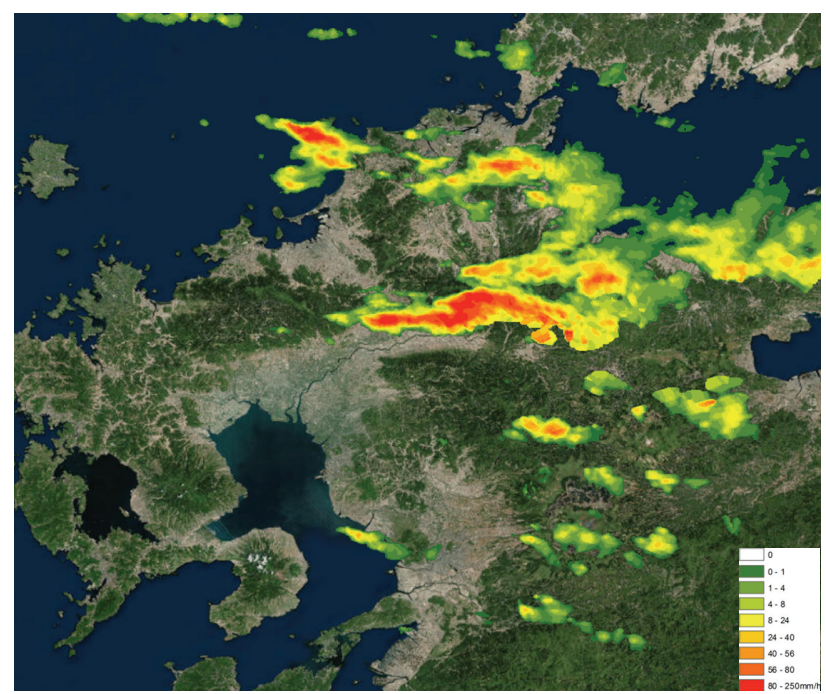

Figure 8. Result of inputting rainfall information of the X-band MP radar into GIS (2017.7.5 13:00).

\section{APPLICATION TO DISASTER PREVENTION INFORMATION}

\subsection{Sediment disaster}

The downpour of July 2017 and the resultant large-scale debris flow caused much personal suffering and severe material damage. The sediment disasters were concentrated in Fukuoka Prefecture (Asakura City) and Oita Prefecture (Hita City). Sediment breakdown was reported at 232 sites in Fukuoka Prefecture and 43 sites in Oita Prefecture. Tables 2 and 3 shows the damage situation of the sediment disasters in both prefectures. Many buildings (515) were damaged in Asakura City of Fukuoka Prefecture. 


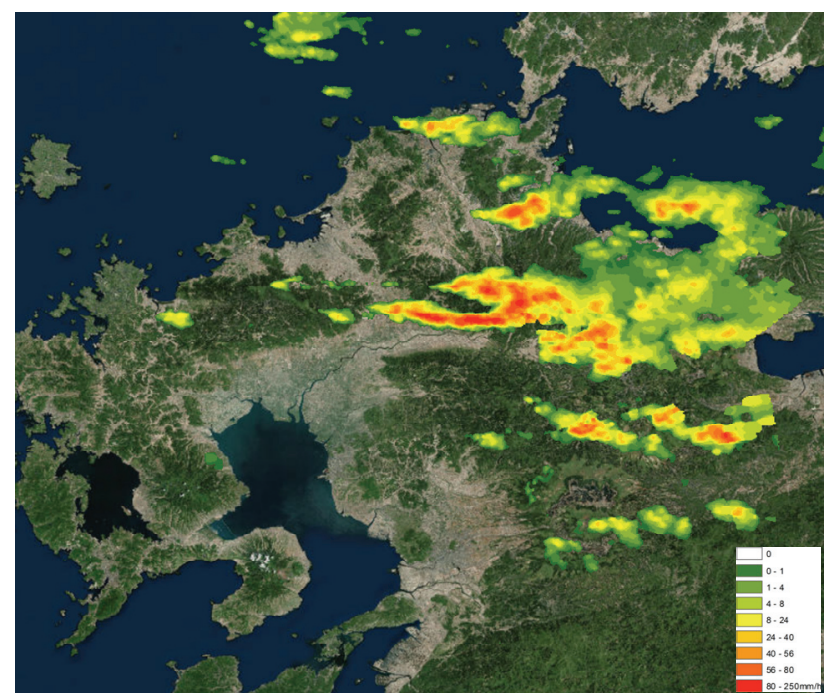

Figure 9. Result of inputting rainfall information of the X-band MP radar into GIS (2017.7.5 14:00).

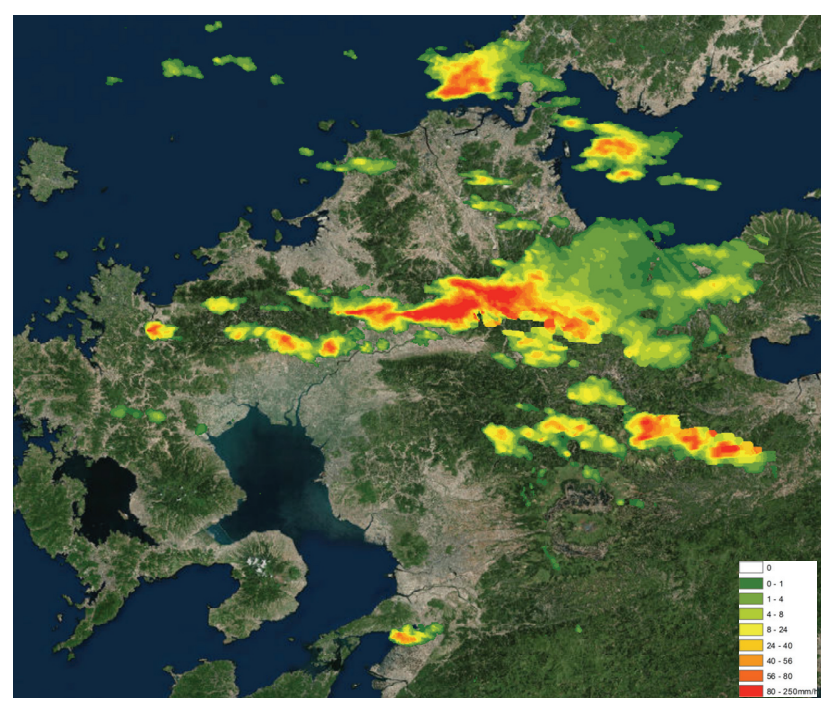

Figure 10. Result of inputting rainfall information of the X-band MP radar into GIS (2017.7.5 15:00).

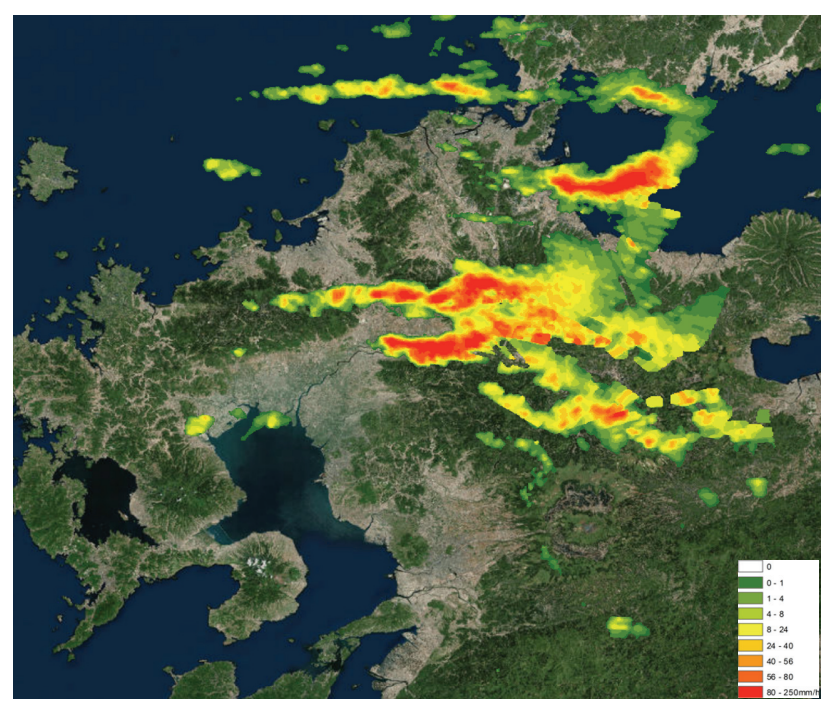

Figure 11. Result of inputting rainfall information of the X-band MP radar into GIS (2017.7.5 16:00).

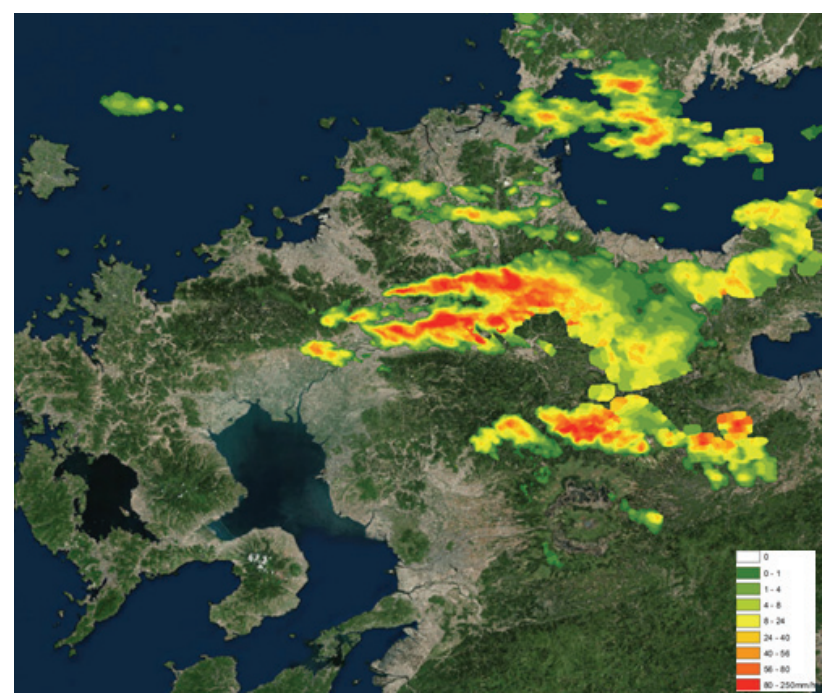

Figure 12. Result of inputting rainfall information of the X-band MP radar into GIS (2017.7.5 17:00).

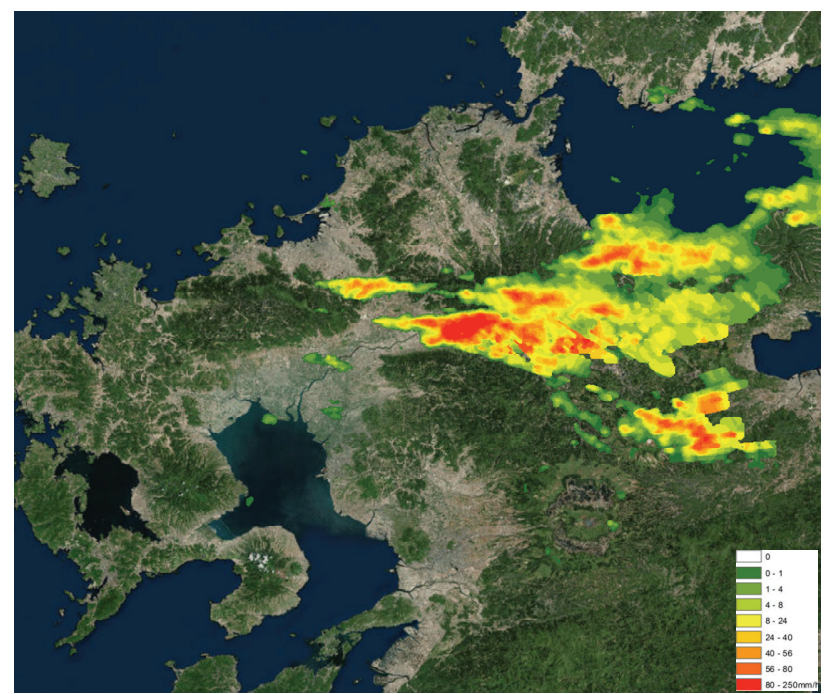

Figure 13. Result of inputting rainfall information of the X-band MP radar into GIS (2017.7.5 17:00).

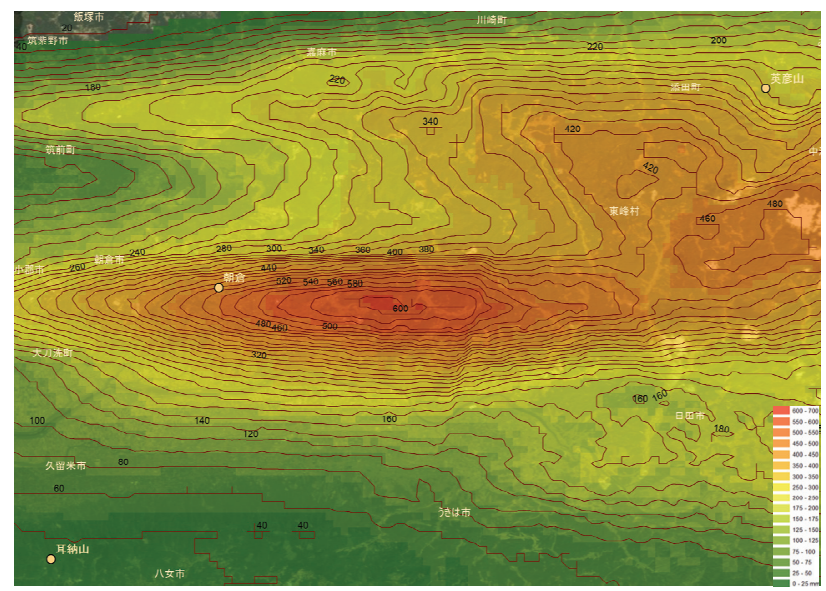

Figure 14. Analysis of rainfall data collected by the X-band MP radar (2017.7.5 01:00-24:00). 
The especially severe building damage in Asakura City was caused by the torrential amount of rainwater deposited during the downpour.

Personal suffering was also high in Asakura City. The MLIT reported 20-22 deaths in the city. Many of the geological features struck by the downpour in this region are composed of granite, which is easily weathered. The area covered by decomposed granite soil in Asakura City was dislodged, causing a shallow landslide. Moisture had accumulated in the soil under the continued rainfall. Post-disaster investigation revealed decomposed weathered granite on the ground and outflows of comparatively hard materials such as sedimentary rocks. Figure 15 displays the sites of sediment disasters (landslides) revealed in the satellite photograph. Figures 16-19 are photographs of the landslide disaster sites in Asakura City and Hita City, and Figure 20 visualizes the rainfall measured by the X-band MP radar. Table 2-3 shows the damage situation of the sediment disasters (Fukuoka Prefecture and Oita Prefecture).

Table 2. Damage situation of the sediment disasters in Fukuoka Prefecture. (MLIT January, 2018)

\begin{tabular}{|c|c|c|c|c|c|c|}
\hline \multirow{2}{*}{ Disaster } & \multicolumn{3}{|c|}{ Personal suffering } & \multicolumn{3}{c|}{ Building damage } \\
\cline { 2 - 7 } & dead & Missing & injured & $\begin{array}{c}\text { Complete } \\
\text { destruction }\end{array}$ & $\begin{array}{c}\text { half } \\
\text { collapse }\end{array}$ & $\begin{array}{c}\text { Partial } \\
\text { damage }\end{array}$ \\
\hline debris flow & $\underline{19}$ & $\underline{2}$ & & $\underline{181}$ & $\underline{149}$ & $\underline{69}$ \\
\hline landslide & 1 & & & $\underline{26}$ & $\underline{36}$ & $\underline{54}$ \\
\hline Total & $\underline{\mathbf{2 0}}$ & $\underline{\mathbf{2}}$ & & $\underline{\mathbf{2 0 7}}$ & $\underline{\mathbf{1 8 5}}$ & $\underline{\mathbf{1 2 3}}$ \\
\hline
\end{tabular}

Table 3. Damage situation of the sediment disasters in Oita Prefecture. (MLIT January, 2018)

\begin{tabular}{|c|c|c|c|c|c|c|}
\hline \multirow{2}{*}{ Disaster } & \multicolumn{2}{|c|}{ Personal suffering } & \multicolumn{3}{c|}{ Building damage } \\
\cline { 2 - 7 } & dead & Missing & injured & $\begin{array}{c}\text { Complete } \\
\text { destruction }\end{array}$ & $\begin{array}{c}\text { half } \\
\text { collapse }\end{array}$ & $\begin{array}{c}\text { Partial } \\
\text { damage }\end{array}$ \\
\hline debris flow & & & & 5 & 1 & 2 \\
\hline landslide & 1 & & 2 & & & 13 \\
\hline Total & 1 & & $\underline{2}$ & $\underline{5}$ & 1 & $\underline{15}$ \\
\hline
\end{tabular}

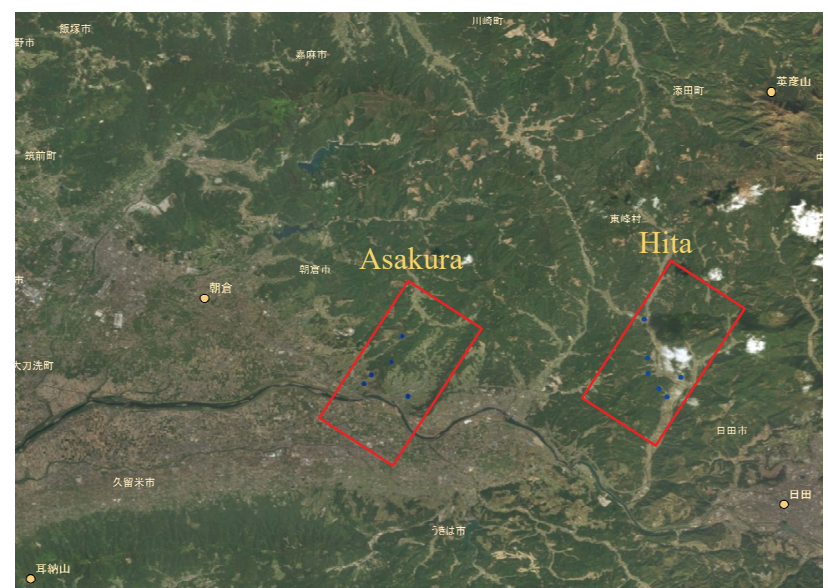

Figure 15. Site of landslide disaster.

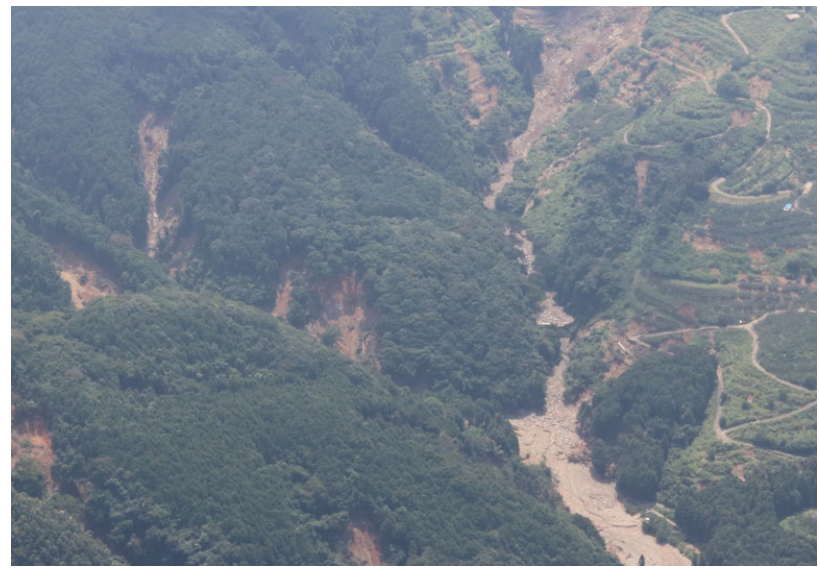

Figure 16. Sediment disasters in Asakura City (1).

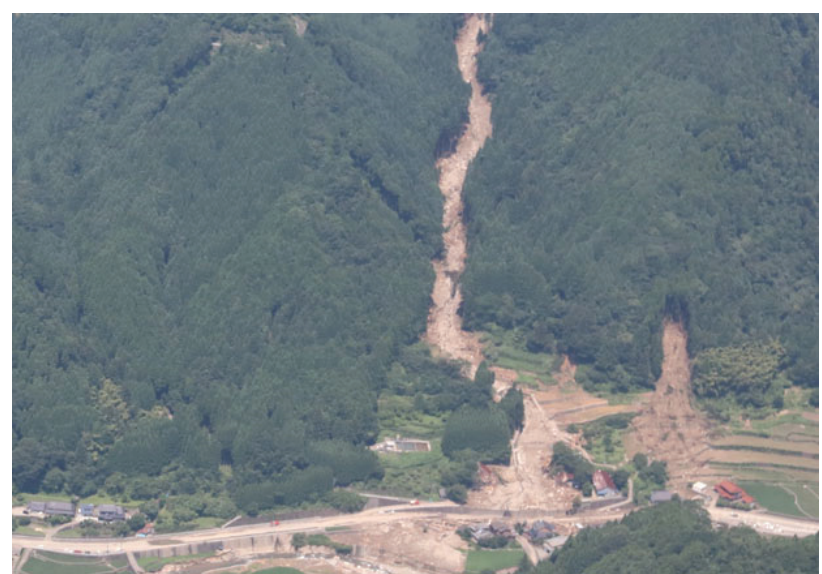

Figure 17. Sediment disasters in Asakura City (2). 


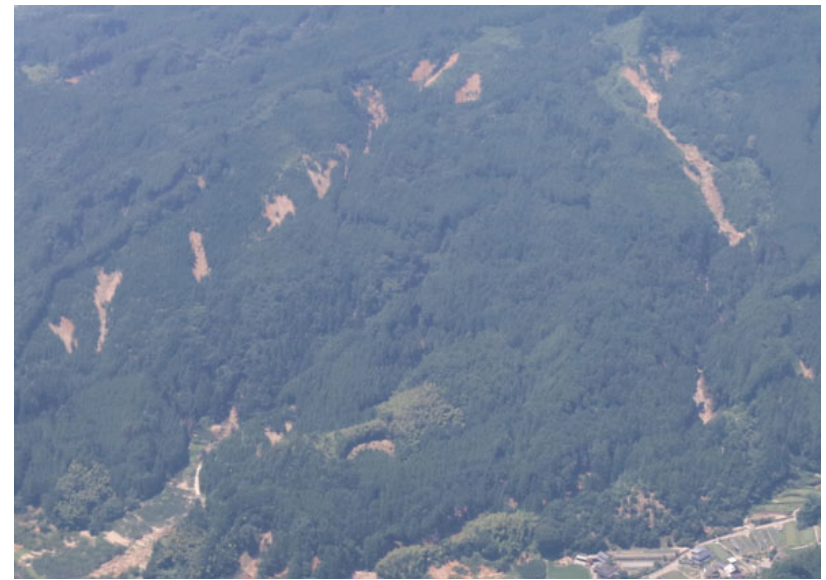

Figure 18. Sediment disasters in Hita City (1).

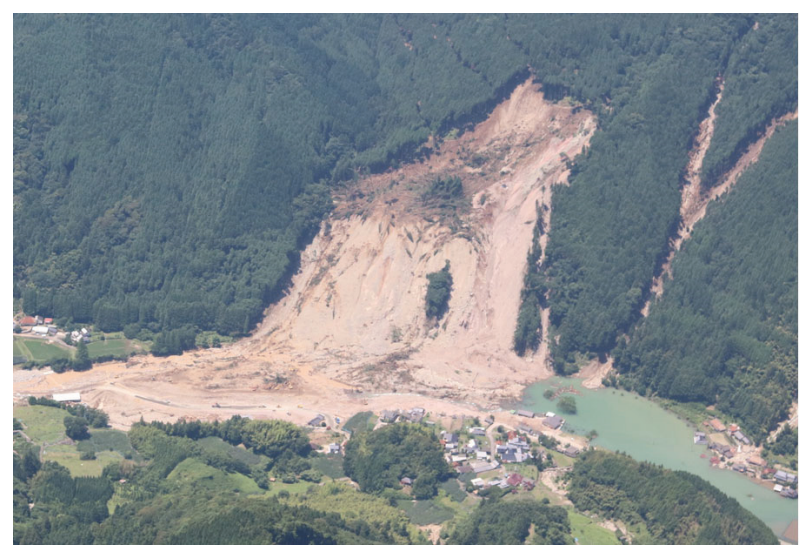

Figure 19. Sediment disasters in Hita City (2).

\subsection{Application to disaster prevention}

The local government is investigating sediment disasters in the Fukuoka and Oita regions of Japan (represented by Asakura City and Hita City, respectively). Many of the sediment disasters were likely generated by the heavy rain. Sediment danger is alerted during heavy rainfalls $(\geq 20 \mathrm{~mm} / \mathrm{h})$ or when the total rainfall exceeds $100 \mathrm{~mm}$. Heavy and persistent rains might precede a landslide disaster.

Japan has implemented a precaution shelter standard against sediment disaster (Table 4). In the event of potential sediment damage and risk to human life, the local government orders residents to evacuate to the directed shelter. During a large-scale disaster occurring once every several decades, the JMA announces an emergency warning (Table 5). The evacuation order provides shelter preparation information, an evacuation order, and an evacuation directive. When the landside-disaster risk is raised by heavy rain, the local government and JMA jointly announce a landslide-disaster alert. Our new system can analyze the amount of accumulated rainfall, which is important for landslide disaster prevention.
Table 4. Precaution shelter standards during a sediment disaster

\begin{tabular}{|c|c|c|c|}
\hline Rainfall for one hour $(\mathrm{mm})$ & Shelter preparation information & Evacuation order & Evacuation directive \\
\hline $\begin{array}{l}\text { Continuous rainfall reaching } \\
100 \mathrm{~mm} \text { or more on the } \\
\text { previous day. }\end{array}$ & $\begin{array}{l}\text { Daily rainfall reaching } 50 \mathrm{~mm} \text { or } \\
\text { more on this day. }\end{array}$ & \begin{tabular}{|l|}
$\begin{array}{l}\text { Daily rainfall reaching } 50 \mathrm{~mm} \text { or } \\
\text { more on this day. } \\
\text { Heay rain (30 mm or more per hour) } \\
\text { expected immediately. }\end{array}$ \\
\end{tabular} & $\begin{array}{l}\text { When the forerunning } \\
\text { phenomenon of a landslide } \\
\text { disaster is admitted. } \\
\text { When the landslide disaster is } \\
\text { generated. }\end{array}$ \\
\hline $\begin{array}{l}\text { Continuous rainfall reaching } \\
40-100 \mathrm{~mm} \text { on the previous } \\
\text { day }\end{array}$ & $\begin{array}{l}\text { Daily rainfall reaching } 80 \mathrm{~mm} \text { c } \\
\text { more on this day. }\end{array}$ & $\begin{array}{l}\text { Daily rainfall reaching } 80 \mathrm{~mm} \text { or } \\
\text { more on this day. } \\
\text { Heayy rain }(30 \mathrm{~mm} \text { or more per hour) } \\
\text { expected in the near future. }\end{array}$ & $\begin{array}{l}\text { When the forerunning } \\
\text { phenomenon of a landslide } \\
\text { disaster is admitted. } \\
\text { When the landslide disaster is } \\
\text { generated. }\end{array}$ \\
\hline $\begin{array}{l}\text { No rainfall recorded up to } \\
\text { the previous day. }\end{array}$ & $\begin{array}{l}\text { Daily rainfall reaching } 100 \mathrm{~mm} \\
\text { or more on this day. }\end{array}$ & $\begin{array}{l}\text { Daily rainfall reaching } 100 \mathrm{~mm} \text { or } \\
\text { more on this day. } \\
\text { Heavy rain }(30 \mathrm{~mm} \text { or more) } \\
\text { expected in the near future. }\end{array}$ & $\begin{array}{l}\text { When the forerunning } \\
\text { phenomenon of a landslide } \\
\text { disaster is admitted. } \\
\text { When the landslide disaster is } \\
\text { generated. }\end{array}$ \\
\hline
\end{tabular}

Table 5. JMA Criteria for Emergency Warnings

\begin{tabular}{|c|l|l|}
\hline Phenomenon & \multicolumn{1}{|c|}{ Criteria } \\
\hline Heavy rain & $\begin{array}{l}- \text { Heavy rainfall with a level of intensity observed only once every few } \\
\text { decades is predicted } \\
\text { Or: } \\
\text { Heavs } \\
\text { have a level of intensity } \\
\text { observed only once every few decades or an extratropical cyclone with } \\
\text { comparable intensity. }\end{array}$ \\
\hline Storm & $\begin{array}{l}\text { A Stormis predicted } \\
\text { Storm surge }\end{array}$ & $\begin{array}{l}\text { A storm surge is predicted } \\
\text { expected to have a level of } \\
\text { intensity observed only once every } \\
\text { few decades or an } \\
\text { extratropical cyclone with } \\
\text { comparable intensity. }\end{array}$ \\
\hline High waves & $\begin{array}{l}\text { High waves are predicted } \\
\text { Snowstorm }\end{array}$ & $\begin{array}{l}\text { A snowstorm is predicted in association with an extratropical cyclone } \\
\text { expected to have a } \\
\text { level of intensity observed only once every few decades. }\end{array}$ \\
\hline Heavy snow & $\begin{array}{l}\text { Heavy snowfall with a level of intensity observed only once every few } \\
\text { decades is predicted. }\end{array}$ \\
\hline
\end{tabular}

\section{CONCLUSIONS}

Monitoring the accumulated rainfall is crucial for disaster prevention. The JMA provides a ransituation (rain strength) standard showing the hazard levels of hourly rainfall amounts. These hazard levels are important for estimating disaster occurrences. Using GIS, our new system visualizes the 24-h rainfall accumulation (01:00-24:00 during the July 5 downpour) measured by the X-band MP radar. To check the method, we compared our results with the accumulated rainfall measured by AMeDAS at the disaster sites in Asakura and Hita cities. The images were very similar. Although the hourly rainfall was slightly larger in the AMeDAS data than in the Xband MP radar data, the difference was not critical. The areas of maximum accumulated rainfall (up to $200 \mathrm{~mm}$ ) in Asakura City and Hita City coincided with the sites of debris flow and landslide disasters. In summary, the X-band MP radar appears to be necessary for precise heavy-rain location, owing to its higher resolution than AMeDAS and C-band radar. Had the refuge information been appropriately issued in Asakura and Hita cities during the 5-6 July flooding, the human losses would have been greatly reduced.

\section{ACKNOWLEDGMENTS}

We thank MLIT for providing X-band MP radar data and the technical data. We thank JMA for weather information and technological material. This work was supported by MEXT Grant-in-Aid for Scientific Research (C) Grant Number 25350510 


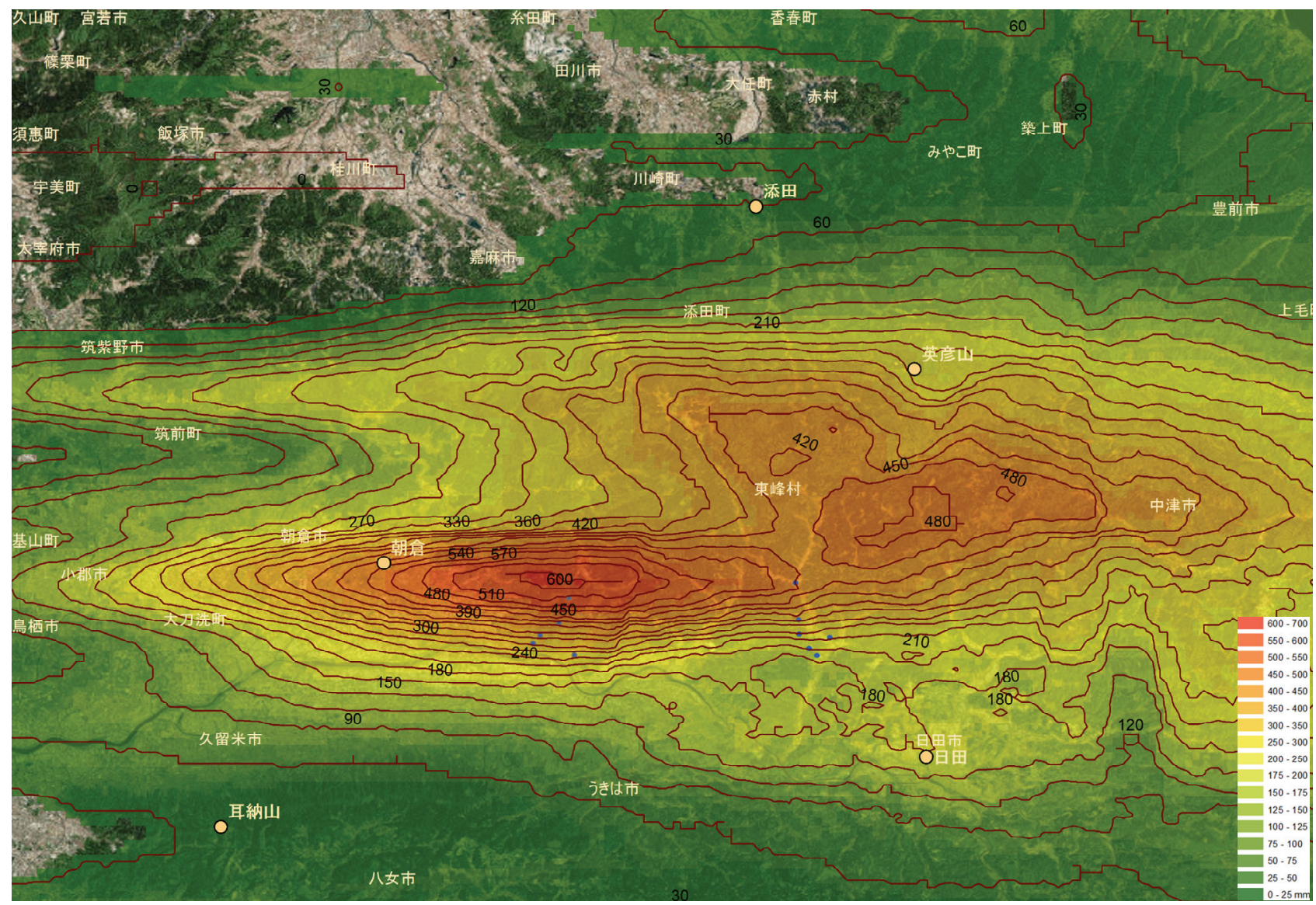

Figure 20 Amount of accumulated rainfall measured by the X-band MP radar (2017 1:00-24:00, July 5).

\section{REFERENCES}

Yamamoto, H, Yamasaki, T., 2017. Characteristics of heavy rainfall and disaster in northern part of Kyushu on July 5, 2017, J. JSNDS, Vol.36, No.3, pp. 257-279.

Nishio, M., Mori, M., 2015. The Web-based accumulated rainfall amount monitoring system by X-band MP radar, Journal of Flood Risk Management, in published online: 21 AUG., jfr3.12196.

Kato, A., Maki, K., 2009. Localized Heavy Rainfall near Zoshigaya: Tokyo, Japan on 5 August 2008 Observed by Xband Polarimetric Radar. SOLA, 5, pp. 89-92.

Sakurai, N., Iwanami, K., Maesaka, T., Suzuki, S., Shimizu, S., Misumi, R., Misumi, R., Kim, D., Maki, M., 2012. Case Study of Misoscale Convective Echo Behavior Associated with Cumulonimbus Development Observed by Ka-band Doppler Radar in the Kanto Region: Japan. SOLA, 8, pp. 107-110.

Kobayashi, F., Takano, T., Takamura, T., 2011. Isolated Cumulonimbus Initiation Observed by $95-\mathrm{GHz}$ FM-CW Radar, $\mathrm{X}$-band Radar, and Photogrammetry in the Kanto Region: Japan. SOLA, 7, pp. 125-128

Hirano, K., Maki, M., 2010. Method of VIL Calculation for Xband Polarimetric Radar and Potential of VIL for Nowcasting of Localized Severe Rainfall: Japan. SOLA, 6, pp. 89-92.
Diss, S., Testud, J., Lavabre, J., Ribstein, P., Moreau, E., Parent du Chatelet, J., 2009. Ability of a dual polarized X-band radar to estimate rainfall: Advances in Water Resources, 32-7, pp. 975-985.

Vieux, B.E., Imgarten, J.M., 2012. On the scale-dependent propagation of hydrologic uncertainty using high-resolution Xband radar rainfall estimates: Atmospheric Research, 103, pp. 96-105.

Thorndah, S., Rasmussen, M.R., 2012. Marine X-band weather radar data calibration: Atmospheric Research, 103, pp. 33-44.

Anagnostoua, M.N., Kalogirosb, J., Anagnostou, E.N., Tarolli, M., Papadopoulos, A., Borga, M., 2010. Performance evaluation of high-resolution rainfall estimation by X-band dual-polarization radar for flash flood applications in mountainous basins: Journal of Hydrology, 394, pp. 4-16.

Nishio, M., Mori, M., 2012. Web-based Delivery System for Disaster Prevention Information using a New JMA DPI XML Format and AMeDAS Data: ISPRS Ann ls of the Photogrammetry, Remote Sensing and Spatial Information Sciences, Volume 1-4, pp. 23-27.

GeoServer. GeoServer Documentation web site. Available at http://www.jma.go.jp/ (5 Mar. 2018). 